autor przyjmuje zasadę konsekwentnej symetrii. Omówieniu genezy i funkcjonalności danego narzędzia towarzyszy wskazanie obszarów, do jakich może ono zostać wykorzystane w bibliotekach. Klarowną charakterystykę wzbogacają liczne przykłady praktycznych rozwiązań, pochodzące zarówno z książnic zagranicznych, jak i polskich.

Istotnym walorem publikacji jest jej język. Autor bez zbędnego narzucania się i huraoptymizmu - tak często towarzyszącego nowoczesnym technologiom - w sposób kompetentny, a jednocześnie wyważony i bardzo przystępny, opisuje możliwości wykorzystywania narzędzi Web $2.0 \mathrm{w}$ instytucjach bibliotecznych. Omawiając poszczególne aspekty tego zagadnienia, nie przyjmuje roli arbitra i nie

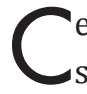
elem wydanego przez Muzeum Historii Polskiego Ruchu Ludowego niewielkiego wydawnictwa, jak napisali Władysław Marek Kolasa i Grzegorz Nieć, jest „ukazanie stanu badań nad prasą ruchu ludowego, krótka charakterystyka oraz ocena dostępnych prac z tego zakresu, wreszcie zwrócenie uwagi na najważniejsze potrzeby, najdotkliwsze luki i braki w tym obszarze. Zadaniem naszym - napisali dalej autorzy - jest zatem zarówno dokonanie inwentaryzacji opracowań, rekomenduje zastosowania takiego czy innego narzędzia. Ten wybór pozostawia pracownikom bibliotek, uprzedzając jednak, że pełne urzeczywistnianie koncepcji Biblioteki 2.0 to ogromne wyzwanie zarówno dla użytkowników, jak i bibliotekarzy. W świetle badań i analiz przeprowadzonych przez Gmiterka - wyzwanie opłacalne, bo pozwalające bibliotekom obrócić możliwości stwarzane przez nowoczesne technologie na swoją korzyść, a tym samym zatroszczyć się o dobro obecnych i przyszłych użytkowników oraz własny wizerunek.

\section{Małgorzata Kowalska}

Instytut Informacji Naukowej i Bibliologii Uniwersytetu Mikołaja Kopernika w Toruniu

\section{Władystaw Marek Kolasa, Grzegorz Nieć, Bibliografia historii prasy polskiego ruchu ludowego, Warszawa: Muzeum Historii Polskiego Ruchu Ludowego 2012, 104 s., ISBN 978-83-62171-43-9}

DOI: $10.12775 /$ TSB. 2013.012

jak i sprowokowanie dyskusji oraz - co byłoby najbardziej pożądane - zainspirowanie badaczy do podjęcia pewnych 
tematów" (s. 11). Na wstępie trzeba przyznać, że to niezwykle ambitne cele, zwłaszcza jeżeli spojrzymy na objętość liczącej zaledwie 104 strony książki. Jednak dalsza lektura pokazuje konsekwentną realizację nakreślonych zadań.

Wbrew oczekiwaniom autorzy nie rozpoczęli od wstępu, charakteryzującego całość opracowania, ale przedstawili Stan badań nad prasa polskiego ruchu ludowego, rozpoczynając od definicji terminu prasa ruchu ludowego, oddzielając go od pojęcia prasy dla ludu, następnie przywołali dwa podstawowe opracowania dotyczące prasy ludowej: Ireny Turowskiej-Bar Polskie czasopisma o wsi i dla wsi od XVIII w. do r. 1960. Materiały bibliograficzno-katalogowe (Warszawa 1963) oraz Stanisława Stępnia Prasa ludowa w Polsce. Zarys historyczny (Warszawa 1984). Obie publikacje rzeczywiście stanowią dla badaczy prasy ruchu ludowego „fundament" wszelkich poczynań, jednak ich wartości nie można porównywać. Praca Turowskiej-Bar, mimo licznych błędów, stanowi punkt wyjścia do dalszych badań, nawet jeżeli podejdziemy do zebranego materiału krytycznie, a obszerny wstęp Stanisława Lato to pierwsza próba scharakteryzowania, zgodnie z czasami, w jakich przyszło autorowi ją pisać, zapomnianego, niebadanego dotąd typu czasopiśmiennictwa. Z kolei monografia Stępnia to niewątpliwie plagiat, któremu nie warto było w przedstawianej bibliografii poświęcać aż tyle miejsca. Może w tej części prezentowanej publikacji należałoby odnieść się do zawierających również opisy bibliograficzne dotyczące prasy Materiałów do bibliografii historii ruchu ludowego i zagadnień społecznych wsi 1861-1961 (druki zwarte) Stanisława Gizy i Czesława Wycecha (Warszawa 1964).

Niezbyt budująca jest konkluzja tej części pracy Kolasy i Niecia. Autorzy stwierdzili: „Nie umniejszając w niczym wadze szeregu rozpraw i przyczynków, jakie w ciągu ostatnich dziesięcioleci poświęcono prasie ludowej, przyznać trzeba, że bibliografia prasoznawcza w tym zakresie jest bogata pozornie" (s. 28). Stąd zaproponowane postulaty badawcze, z którymi niewątpliwie trzeba się zgodzić: zestawienie bibliograficzne tytułów czasopism ludowych; rzeczowa, wolna od wszelkiej ideologii synteza dziejów prasy ruchu ludowego; monograficzne opracowanie dorobku publicystycznego działaczy tej formacji politycznej; a także badania szczegółowe uwzględniające np. pomijane dotąd wydawnictwa ciągłe Królestwa Polskiego i zaboru pruskiego, osiągnięcia prasowe Zjednoczonego Stronnictwa Ludowego i przyczyny ich upadku czy nowe inicjatywy periodyczne Polskiego Stronnictwa Ludowego w okresie transformacji ustrojowej.

Drugą część prezentowanego wydawnictwa stanowi bibliografia obej- 
mująca piśmiennictwo dotyczące historii prasy polskiego ruchu ludowego od końca XIX w. do współczesności, a nie jak napisano w części wstępnej, zestawienia bibliograficznego "historii polskiego ruchu ludowego". Zarejestrowano w niej 312 pozycji, wśród których 46 to książki, 32 - fragmenty w monografiach oraz 234 - artykuły. Autorzy zaznaczyli, że bibliografia ma charakter selekcyjny, obejmuje piśmiennictwo naukowe oraz szczególnie wartościowe materiały wspomnieniowe i dokumentacyjne. Analizując bibliografię, można zauważyć, że całość podzielono na dwie części. Pierwszą stanowią Opracowania ogólne, drugą Poszczególne okresy: prasa ludowa do 1918 r., prasa ludowa w latach 1918-1939 (tu osobne miejsce zajmuje: chłopska prasa komunistyczna 1918-1939), prasa ludowa w latach 1939-1945, prasa ludowa w latach 1945-1989, prasa ludowa po 1989 r. W obrębie poszczególnych działów chronologicznych wyszczególniono wydawnictwa o charakterze ogólnym, publikacje dotyczące poszczególnych regionów, tytułów, osób i typów prasy. Wydaje się, że autorzy niepotrzebnie nieco skomplikowali ten układ, zwłaszcza że rzecz dotyczy zaledwie 312 opisów bibliograficznych i nie w każdym okresie dziejów prasy ruchu ludowego znalazły się publikacje, które można przyporządkować do wyszczególnionych części bibliografii.

Ponieważ Bibliografia Kolasy i Niecia, jak już zaznaczono, ma charakter selekcyjny, trudno spierać się, dlaczego pewne publikacje zostały uwzględnione, a inne nie. Zapewne wszystkie osoby analizujące zamieszczone w wydawnictwie opisy bibliograficzne będą miały swoją własną wizję „,selekcji". Ten wybór uświadamia jednak, że zgłoszone wcześniej postulaty badawcze są słuszne, prasa ruchu ludowego stanowi ciekawy fragment historii prasy polskiej i należy uznać, że nowo wydana Bibliografia jest pierwszym krokiem do stworzenia pełnej syntezy prasy, używając terminologii Ireny Turowskiej-Bar, „dla wsi”.

\section{Grażyna Gzella}

Instytut Informacji Naukowej i Bibliologii Uniwersytetu Mikołaja Kopernika w Toruniu 